\title{
EFFICACY OF CINNAMON OIL TO PROLONG THE SHELF-LIFE OF PASTEURISED, ACIDIFIED, AND AMBIENT STORED PAPAYA PULP
}

\author{
U. BINDUHEVA a and P.S. NEGI* \\ Fruit and Vegetable Technology Department, CSIR-Central Food Technological Research Institute, \\ Mysore 570020, India \\ ${ }^{a}$ Current Address: Research Scientist, Industrial Technology Institute, Colombo, Sri Lanka
}

(Received: 21 December 2012; accepted: 5 April 2013)

\begin{abstract}
This study was conducted to develop a low cost method to preserve papaya (Carica papaya L.) pulp at ambient temperature with a combination of treatments including acid, heat, and cinnamon oil. Papaya pulp processed without

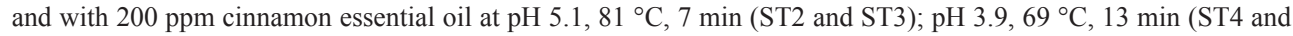
ST5); and $\mathrm{pH} 4.5,75^{\circ} \mathrm{C}, 15 \mathrm{~min}$ (ST6 and ST7) was stored for 8 weeks at ambient temperature $\left(28 \pm 2{ }^{\circ} \mathrm{C}\right)$. The cinnamaldehyde content of the papaya pulp treated with cinnamon oil decreased significantly during storage. ST5 and ST7 retained significantly higher $\beta$-carotene contents and lightness values compared to ST4 and ST6 during storage. The results indicated that acidification of papaya pulp to $\mathrm{pH} 4.5$ and pasteurization at $75^{\circ} \mathrm{C}$ for 15 min with $200 \mathrm{ppm}$ cinnamon oil can be applied to obtain safe and high quality product, which is stable for 8 weeks at ambient temperature.
\end{abstract}

Keywords: antimicrobial agents, carotenoids, essential oils, preservation, shelf life

Consumption of papaya (Carica papaya L.) as a fruit is beneficial, since it is rich in vitamins and minerals. Papaya pulp is used as a raw material for processing various fruit products and it is exported from tropical countries to the European community and the United States. Currently papaya pulp is preserved by sterilization or pasteurization with chemical preservatives followed by refrigeration or freezing. Beside destruction of heat labile nutrients such as vitamin C, sterilization also significantly alters the organoleptic properties of papaya. With increase in "green consumerism", consumers are demanding foods that are preserved with natural compounds to ensure safety against food- borne pathogens. Novel methods, such as high hydrostatic pressure and ohmic heating, were found successful in ensuring the food safety and quality, however, the cost of production is relatively high (TAJKARIMI et al., 2010). Therefore, the need of hour is to develop an appropriate low cost method, which can ensure a high quality and safe produce after long term storage.

Cinnamon is a spice which has been used in culinary practices and pharmaceutical industry for a long time. It is recognized as GRAS substance by the US FDA. Major flavour compounds of cinnamon, cinnamaldehyde and eugenol, exert strong antimicrobial properties against foodborne pathogens in various in-vitro studies (TAJKARIMI et al., 2010). Although a few studies have reported its efficacy in food system alone (GuYNOT et al., 2005) or in combination with heating (AMALARADJou et al., 2010), to our knowledge no study was

\footnotetext{
* To whom correspondence should be addressed. Phone: +91-821-2515653; fax: +91-821-2517233; e-mail: psnegi@cftri.res.in
} 
conducted to measure the antimicrobial effect of cinnamon and its oil in low acidic foods. Therefore, the aim of this study was to evaluate the effect of cinnamon essential oil in combination with acidification and pasteurization on microbiological, physicochemical, and organoleptic properties of papaya pulp during 8 -week storage at $28 \pm 2{ }^{\circ} \mathrm{C}$.

\subsection{Materials}

\section{Materials and methods}

Commercially available ripe papayas were purchased from fruit and vegetable market, Mysore, India. Cinnamon essential oil and polypropylene bags were purchased from local vendors, HPLC solvents from Rankem Ltd. (Delhi, India) and Spectrochem (Mumbai, India), analytical chemicals from Qualigens (Mumbai, India), and microbiological media and sterilized Petri plates were from HiMedia (Mumbai, India).

\subsection{Preparation of samples}

Whole papaya fruits were washed and surface disinfected with sodium hypochlorite solution $(2 \%, v / v)$. The fruits were subjected to steam treatment for three min and cooled to ambient temperature in 200 ppm chlorine solution. Papaya fruits were cut open; pulp was scooped out and crushed finely in a mixer grinder. The $\mathrm{pH}$ of the papaya pulp samples was adjusted using anhydrous citric acid.

\subsection{Preliminary study}

For optimization of papaya pulp processing, a total of 15 treatment combinations were selected through central composite randomized design (CCRD) using $\mathrm{pH}$, temperature, and time in the range of 3.5 to $5.5,65$ to $85{ }^{\circ} \mathrm{C}$, and 5 to $15 \mathrm{~min}$, respectively (Table 1 ). Pectinesterase (PE) activity, benzylisothiocyanate (BITC) content and total plate counts (TPC) were evaluated as the responses of the above treatments for optimizing process parameters. For determination of optimum concentration of cinnamon oil in papaya pulp, cinnamon essential oil was added at 50, 100, 200, 300, 500, and 5000 ppm concentrations by mixing into the pulp using a blender. Papaya pulp was processed, along with the control (without any treatment) with selected treatment combinations. The samples were stored under ambient temperature for one week, and odour and TPC were evaluated. Concentration of cinnamon oil resulting in the minimum perceived odour of cinnamon and the maximum $\log$ reduction was selected for storage study.

\subsection{Storage study}

After the preparation of samples (section 1.2) cinnamon essential oil (200 ppm) was added, $50 \mathrm{~g}$ pulp for the selected treatments (Table 1) was packed in polypropylene bags (decontaminated by exposing to ultraviolet rays) and stored at ambient temperature $\left(28 \pm 2{ }^{\circ} \mathrm{C}\right)$ away from direct sunlight. Chemical parameters and microbiological quality of stored papaya pulp were evaluated at two weeks intervals. The sensory quality of stored papaya pulp was evaluated at the end of storage. 
Table 1. Treatment combinations for papaya processing for preliminary and storage studies

\begin{tabular}{lcccc}
\hline Treatment & $\mathrm{pH}$ & Temperature $\left({ }^{\circ} \mathrm{C}\right)$ & Time $(\mathrm{min})$ & Treatment used for storage study* \\
\hline $\mathrm{T} 1$ & 3.9 & 69 & 7 & \\
$\mathrm{~T} 2$ & 5.1 & 69 & 7 & \\
T3 & 3.9 & 81 & 7 & T4 (ST2) \\
T4 & 5.1 & & 7 & T4 with 200 ppm cinnamon (ST3) \\
& & 61 & 13 & T5 (ST4) \\
T5 & 3.9 & & & T5 with 200 ppm cinnamon (ST5) \\
& & 69 & 13 & \\
T6 & 5.1 & 81 & 13 & \\
T7 & 3.9 & 81 & 13 & \\
T8 & 5.1 & 75 & 10 & \\
T9 & 3.5 & 75 & 10 & \\
T10 & 5.5 & 65 & 10 & \\
T11 & 4.5 & 85 & 10 & \\
T12 & 4.5 & 75 & 5 & \\
T13 & 4.5 & 75 & 15 & T14 (ST6) \\
T14 & 4.5 & & & T14 with 200 ppm cinnamon (ST7) \\
T15-21 & 4.5 & 75 & & \\
\hline
\end{tabular}

*In storage study, raw papaya pulp having pH of 5.46 without added cinnamon oil (Control) and with 200 ppm cinnamon oil (ST1) were also included

\subsection{Pectinesterase (PE) activity}

Ten g of papaya pulp was mixed with $100 \mathrm{ml}$ of $1 \%$ pectin-salt solution and its $\mathrm{pH}$ was adjusted to 7.2. The mixture was kept under constant stirring using magnetic stirrer and when $\mathrm{pH}$ dropped to 7.0 the time was noted. The $\mathrm{pH}$ was maintained at $7.0 \pm 0.1$ by adding $0.02 \mathrm{~N}$ $\mathrm{NaOH}$ from the burette and the timer was stopped when $\mathrm{pH}$ became stable at 7.0 (RANGANNA, 1997). PE activity was calculated using the formula:

$$
P E \text { activity }(\text { unit } \times 1000 \text { per } g \text { pulp })=\frac{\text { millilitres } \mathrm{NaOH} \times \text { normality } \mathrm{NaOH} \times 1000}{\text { time } \times \text { weight of pulp }}
$$

Residual PE activity was calculated using the formula:

$$
\text { Residual PE activity }=\frac{\text { PE activity of sample } \times 100}{\text { PE activity of control }}
$$

\subsection{Benzylisothiocyanate (BITC) content}

The BITC content of papaya pulp was determined as described by NAKAMURA and co-workers (2007), using HPLC (Agilent 1100/1200) with a variable wavelength UV detector and quaternary pump. The column used was ODS-3V, $5 \mu \mathrm{m}$ size, $4.6 \mathrm{~mm}$ id, $250 \mathrm{~mm}$ length (Intersil, Japan) and the injection volume was $20 \mu$ l. Isocratic elution (40\% acetonitrile in water containing $0.1 \%$ trifluoroacetic acid) was done at a rate of $1 \mathrm{ml} \mathrm{min}^{-1}$ and absorbance was monitored at $254 \mathrm{~nm}$. Concentration of BITC of pulp was calculated from the standard curve. 


\subsection{Cinnamaldehyde content}

The cinnamaldehyde content of the treated samples was evaluated according to the method of GuRsale and co-workers (2010). HPLC (section 1.6) with mobile phase of methanol, acetonitrile, and water in the ratio 35:20:45 was used. Cinnamaldehyde was detected at 221 $\mathrm{nm}$ using UV detector. The cinnamaldehyde content in the pulp was calculated from the standard curve.

\section{8. $\beta$-carotene content}

The $\beta$-carotene content was determined essentially by the method described by NAMITHA and co-workers (2011) using HPLC (section 1.6 except column used was ODS-P) and absorbance was monitored at $450 \mathrm{~nm}$. The mobile phase contained methanol and tetrahydrofuran mixed in 95:5 (v:v) ratio. The $\beta$-carotene content in the pulp was calculated from the standard curve.

\subsection{Colour measurement}

$\mathrm{L}$, $\mathrm{a}$, and $\mathrm{b}$ parameters of colour of the stored papaya pulp samples were measured using HunterLab Labscan XE colour measuring system (Hunter Associates Laboratory Inc, Reston, Virginia, USA) as described by NAмітна and co-workers (2011). Hue angle, a measure of true red (true red, $0^{\circ}$ to true yellow, $90^{\circ}$ ) was calculated according to the standard equation as follows:

$$
\text { Hue angle }=\tan ^{-1}[b / a]
$$

\subsection{Microbiological analysis}

A total of $25 \mathrm{~g}$ pulp was aseptically weighted and mixed in $225 \mathrm{ml}$ of sterilized saline solution $(0.85 \% \mathrm{NaCl})$ and if required serial dilutions were made using the same diluent. Papaya pulp samples were evaluated for TPC, yeasts and mould count (YMC), and presence/absence of Salmonella spp., Staphylococcus aureus, and Escherichia coli (VANDERZAnt \& SPlitTstoesser, 1992).

\subsection{Organoleptic properties}

Sensory evaluation of papaya pulp was conducted for acceptability of odour and appearance immediately after processing and after eight weeks of storage under ambient conditions. The three digit coded samples were presented to the panellist in a well-ventilated and adequately lighted room. All panellists (age group 21-24 years) were well versed with the odour of fresh papaya. The panellists were asked to evaluate the odour of the samples on a hedonic scale from 1 : dislike extremely to 9: like extremely (MEILGAARD et al., 1991), and the appearance of pulps was scored based on its retention of homogeneity in the hedonic scale of 1-9, with 1 being very much dissimilar to the freshly pulped papaya and 9 very much similar.

\subsection{Statistical analysis}

PE activity, TPC, YMC, colour values, BITC, cinnamaldehyde, and $\beta$-carotene content of the samples were analysed by ANOVA in Minitab 15 software. Results of sensory evaluation were analysed by Friedman test. 


\section{Results and discussion}

\subsection{Determination of optimum processing conditions for papaya pulp}

2.1.1. Residual PE activity. Residual PE activity, log reduction in TPC and BITC contents of the 15 treatment combinations (Table 1), and control were studied to determine optimum processing conditions. All treated samples showed significantly lower PE activity compared to control $(\mathrm{P}<0.05)$. PE activity was higher in the sample of $\mathrm{pH} 3.9$ as compared to the sample of $\mathrm{pH} 5.1$, processed at similar temperature and time indicating the role of $\mathrm{pH}$ as suggested by RANGANNA (1997), wherein the inactivation of $\mathrm{PE}$ with pasteurization at low $\mathrm{pH}$ took more time. Pasteurization time and temperature also had significant effect on PE activity as pasteurization at $65{ }^{\circ} \mathrm{C}$ for $10 \mathrm{~min}$ resulted in significantly higher PE activity (0.984 units $\times 10^{3} \mathrm{~g}^{-1}$ pulp) compared to samples pasteurized at $75^{\circ} \mathrm{C}\left(0.028\right.$ units $\times 10^{3} \mathrm{~g}^{-1}$ pulp $)$ and 85 ${ }^{\circ} \mathrm{C}\left(0.008\right.$ units $\times 10^{3} \mathrm{~g}^{-1}$ pulp) for $10 \mathrm{~min}$. Pasteurization above $75^{\circ} \mathrm{C}$ significantly reduced $\mathrm{PE}$ activity irrespective of $\mathrm{pH}$, and pasteurization for $15 \mathrm{~min}$ at the temperatures used in the present study $\left(65-85^{\circ} \mathrm{C}\right)$ completely inactivated the enzyme. Increasing pasteurization temperature and time result in significant decrease in PE activity, and complete thermal inactivation of purified papaya $\mathrm{PE}$ occurs at $70{ }^{\circ} \mathrm{C}$ when heated for $5 \mathrm{~min}$ at $\mathrm{pH} 4.0$ (FAYYAZ et al., 1995).

2.1.2. Reduction in total plate count. Papaya naturally has a higher $\mathrm{pH}$ and it is subjected to spoilage by microorganisms. The control samples had the highest TPC, indicating a high level of contamination with natural microflora present in the peel and cross contamination occurring while handling. Survival of spoilage organisms was lower in acidic $\mathrm{pH}$, as the counts were higher (though non-significant) at $\mathrm{pH} 5.1$ compared to the sample of $\mathrm{pH} 3.9$ pasteurized for $7 \mathrm{~min}$ at $69^{\circ} \mathrm{C}$. At similar $\mathrm{pH}$ values, pasteurization at a higher temperature and for longer time resulted in higher log reduction. The influence of heat on the destruction of pathogens in acidified vegetables has also been observed earlier (BREIDT et al., 2004).

2.1.3. BITC content. BITC is an important compound responsible for the bitterness of papaya. Higher BITC contents were observed in samples of $\mathrm{pH} 5.1$, which is close to the natural $\mathrm{pH}$ value of papaya. BITC contents tend to reduce towards acidic $\mathrm{pH}$ values, however, CHANG and co-workers (1973) observed that BITC content was higher in commercial papaya puree adjusted to acidic $\mathrm{pH}$ as compared to fresh fruit.

Based on these results, treatments, $\mathrm{pH} 5.1,81^{\circ} \mathrm{C}, 7 \mathrm{~min}(\mathrm{~T} 4)$; $\mathrm{pH} 3.9,69^{\circ} \mathrm{C}, 13 \mathrm{~min}$ (T5); and $\mathrm{pH} 4.5,75^{\circ} \mathrm{C}, 15 \mathrm{~min}$ (T14), were selected for the optimization of cinnamon oil concentration considering low PE activity, BITC content, and TPC.

2.1.4. Cinnamaldehyde content. Significant differences were observed in the initial TPC among various concentrations of cinnamaldehyde used for the preservation of papaya pulp. Samples treated with $5000 \mathrm{ppm}$ cinnamon oil showed strong antimicrobial effects as it prevented spoilage without the need of any other hurdles. Counts were lower in acidified, pasteurized, and cinnamon oil treated samples compared to untreated samples. After seven days, TPC also increased significantly $(\mathrm{P}<0.05)$ in control and in samples where cinnamon oil was not added, and significant differences were observed among treated and untreated samples. The three hurdles were effective in controlling spoilage of papaya pulp similar to as reported for mango pulp (MorAEs et al., 2011). 
2.1.5. Sensory evaluation. Control samples (without cinnamon oil) gave the characteristic papaya smell in sensory evaluation. The strength of cinnamon smell increased with the concentration of cinnamon oil applied and papaya smell was not detected in samples supplemented with $300 \mathrm{ppm}$ or more cinnamon oil. The panellists commented that $300 \mathrm{ppm}$ or higher cinnamon oil application was not acceptable, since it significantly affects the aroma of the product; however, $200 \mathrm{ppm}$ level was acceptable. Treatment with $200 \mathrm{ppm}$ cinnamon oil retained a slight cinnamon smell after seven days of storage under ambient conditions, which was able to control microbial growth, and therefore it was selected for storage study.

\subsection{Changes in quality of papaya pulp during storage}

2.2.1. Cinnamaldehyde. Changes in cinnamaldehyde contents of treated samples during 8 weeks of storage are reported in Table 2. Cinnamaldehyde content reduced significantly $(\mathrm{P}<0.05)$ during storage, and was negligible in all the samples after 8 weeks of storage. Antimicrobial action of cinnamon essential oil has been ascribed to the compound transcinnamaldehyde, which reacts with proteins and nucleic acids and inhibits the growth of the microorganisms (GUPTA et al., 2008). Probably, the decrease in the content of cinnamaldehyde during storage in present study indicates its utilization for the antimicrobial effect.

Table 2. Cinnamaldehyde and $\beta$-carotene content of papaya pulp during storage

\begin{tabular}{|c|c|c|c|c|c|}
\hline \multirow[b]{2}{*}{ Treatment } & \multicolumn{5}{|c|}{ Storage duration } \\
\hline & \multicolumn{4}{|c|}{ weeks } & 8 \\
\hline \multicolumn{6}{|c|}{ Cinnamaldehyde content (ppm) } \\
\hline ST1 & $130.0 \pm 4.0^{\mathrm{b}}$ & $50.0 \pm 3.5^{\mathrm{c}}$ & $14.0 \pm 1.0^{\mathrm{d}}$ & $3.0 \pm 1.7^{\mathrm{c}}$ & $3.0 \pm 0.0^{\mathrm{b}}$ \\
\hline ST3 & $153.0 \pm 9.5^{\mathrm{a}}$ & $136.0 \pm 5.6^{\mathrm{b}}$ & $81.0 \pm 4.0^{\mathrm{b}}$ & $64.0 \pm 2.5^{\mathrm{b}}$ & $3.0 \pm 0.0^{\mathrm{b}}$ \\
\hline ST5 & $156.0 \pm 4.6^{\mathrm{a}}$ & $147.0 \pm 4.0^{\mathrm{a}}$ & $66.0 \pm 2.8^{\mathrm{c}}$ & $61.0 \pm 2.0^{\mathrm{b}}$ & $3.0 \pm 0.0^{\mathrm{b}}$ \\
\hline ST7 & $159.0 \pm 6.0^{\mathrm{a}}$ & $155.0 \pm 7.1^{\mathrm{a}}$ & $107.0 \pm 5.8^{\mathrm{a}}$ & $99.0 \pm 9.9^{\mathrm{a}}$ & $4.0 \pm 0.0^{\mathrm{a}}$ \\
\hline \multicolumn{6}{|c|}{$\beta$-carotene content ( $\mathrm{mg} \mathrm{kg}^{-1}$ pulp) } \\
\hline ST1 & $2.45 \pm 0.32^{\mathrm{d}}$ & $2.09 \pm 0.16^{\mathrm{d}}$ & $0.69 \pm 0.07^{\mathrm{c}}$ & $0.38 \pm 0.18^{d}$ & $0.22 \pm 0.00^{\mathrm{f}}$ \\
\hline $\mathrm{ST} 2$ & $4.97 \pm 0.06^{\mathrm{a}}$ & $4.20 \pm 0.10^{\mathrm{a}}$ & $1.33 \pm 0.43^{\mathrm{a}}$ & $0.79 \pm 0.09^{\mathrm{c}}$ & $0.46 \pm 0.07^{\mathrm{d}}$ \\
\hline ST3 & $4.20 \pm 0.16^{\mathrm{b}}$ & $4.15 \pm 0.19^{\mathrm{a}}$ & $0.73 \pm 0.19^{\mathrm{bc}}$ & $1.01 \pm 0.02^{\mathrm{b}}$ & $0.91 \pm 0.14^{\mathrm{c}}$ \\
\hline ST4 & $2.47 \pm 0.13^{\mathrm{d}}$ & $2.36 \pm 0.51^{\mathrm{cd}}$ & $0.57 \pm 0.11^{\mathrm{d}}$ & $0.39 \pm 0.01^{\mathrm{d}}$ & $0.33 \pm 0.06^{\mathrm{e}}$ \\
\hline ST5 & $3.12 \pm 0.17^{\mathrm{c}}$ & $2.53 \pm 0.55^{\mathrm{c}}$ & $1.59 \pm 0.30^{\mathrm{a}}$ & $1.30 \pm 0.25^{\mathrm{a}}$ & $1.14 \pm 0.03^{b}$ \\
\hline ST6 & $3.13 \pm 0.05^{\mathrm{c}}$ & $3.07 \pm 0.10^{\mathrm{b}}$ & $0.92 \pm 0.63^{b}$ & $1.07 \pm 0.08^{b}$ & $0.87 \pm 0.21^{\mathrm{c}}$ \\
\hline ST7 & $4.43 \pm 0.08^{\mathrm{ab}}$ & $4.11 \pm 0.15^{\mathrm{a}}$ & $0.89 \pm 0.66^{\mathrm{b}}$ & $1.38 \pm 0.16^{\mathrm{a}}$ & $1.32 \pm 0.10^{\mathrm{a}}$ \\
\hline
\end{tabular}

Values denoted by the same letter in a column for cinnamaldehyde and $\beta$-carotene content did not differ statistically $(\mathrm{P} \leq 0.05)$

2.2.2. $\beta$-carotene. The $\beta$-carotene contents of seven samples were significantly different $(\mathrm{P}<0.05)$ immediately after processing (Table 2$)$. Pasteurized samples with cinnamon oil acidified to $\mathrm{pH} 3.9$ (ST5) and $\mathrm{pH} 4.5$ (ST7) had significantly higher $(\mathrm{P}<0.05) \beta$-carotene contents than their counterparts without cinnamon oil (ST4 and ST6). The higher $\beta$-carotene contents in cinnamon treated samples can be attributed to the cimmanon's ability to inhibit bleaching of $\beta$-carotene by retarding or inhibiting hydroperoxide formation, which attacks the chromophore of $\beta$-carotene. It has been reported that hydroperoxides are 
neutralized by the cinnamon in a concentration dependant manner (BAROTY et al., 2010). The low $\beta$-carotene content of unpasteurized samples observed in the present study may probably be due to oxidation, as oxidation is the major cause of carotenoid destruction during storage and processing (NAMitha \& NeGI, 2010).

2.2.3. Colour. Variation of hue angles and lightness of seven papaya pulp samples stored under ambient conditions showed that the "a" and "b" values of all samples increased up to 4 weeks of storage and reduced thereafter. The "a" values measured after eight weeks storage are significantly lower $(\mathrm{P}<0.05)$ than the initial "a" values. Lightness of all samples reduced significantly $(\mathrm{P}<0.05)$ after four weeks of storage, until the reduction was non-significant. Pasteurized samples with cinnamon oil (ST3) had significantly higher $(\mathrm{P}<0.05)$ "a" value (15.04) and lower lightness value (25.99) compared to pasteurized samples without cinnamon oil (ST2) at the end of storage study (13.62 and 27.19, respectively). Unpasteurized sample without cinnamon oil (ST1) had a lower "a" value (13.5) compared to samples that were pasteurized and with added cinnamon oil (ST3: 15.04; ST5: 14.64; and ST7: 14.61). Samples with cinnamon oil had higher lightness values compared to samples without cinnamon oil, indicating that incorporation of cinnamon oil has a protective effect on the colour of pasteurized papaya pulp, though it could not inhibit browning in unpasteurized samples.

2.2.4. Microbiological parameters. TPC and YMC of papaya samples (seven treatments) were enumerated over 8 weeks of storage. Samples preserved with 200 ppm cinnamon oil only (ST1) showed high TPC and YMC after 6 weeks of storage (more than $5 \log$ CFU g ${ }^{-1}$ ). Control samples, which were not preserved by any of the three measures, showed $3.899 \log$ CFU g ${ }^{-1}$ TPC and $3.45 \log$ CFU g ${ }^{-1}$ YMC soon after packaging, and showed visible microbial growth after 3 days of storage under ambient conditions. Pasteurized pulp ( $81^{\circ} \mathrm{C}$ for $\left.7 \mathrm{~min}\right)$ having pH 5.1 (ST2) showed $2.82 \log \mathrm{CFU} \mathrm{g}^{-1}$ TPC and $2.80 \log \mathrm{CFU} \mathrm{g}^{-1} \mathrm{YMC}^{-1}$ initially, and counts increased to more than $5 \log \mathrm{CFU} \mathrm{g}^{-1}$ after two weeks of storage and continued to increase thereafter. However, similar samples with cinnamon oil (ST3) maintained good quality in terms of TPC and YMC (less than $2 \log \mathrm{CFU} \mathrm{g}^{-1}$ ) throughout the storage, probably due to the synergistic effect of pasteurization and antimicrobial effect of cinnamon oil. Pasteurized pulps of low $\mathrm{pH}$ values (4.5 and lower) with or without cinnamon (ST4, ST5, ST6, ST7) showed statistically similar TPC and YMC (less than $2 \log$ CFU g ${ }^{-1}$ ) throughout the storage. In the present study Staphylococcus aureus, Salmonella spp., and E. coli were not detected in any of the samples tested, initially or during storage, probably due to the hurdle effect of pasteurization, acidification, and cinnamon oil. However, survival of several pathogenic bacteria has also been reported in papaya; such as Escherichia coli O157:H7 in papaya juice held at $4{ }^{\circ} \mathrm{C}$ and $20{ }^{\circ} \mathrm{C}$ (Mutaku et al., 2005) and Salmonella enteritidis in papaya pulp held at $10{ }^{\circ} \mathrm{C}, 20^{\circ} \mathrm{C}$, and $30^{\circ} \mathrm{C}$ (Penteado \& Leitao, 2004).

2.2.5. Sensory scores. Mean scores obtained in sensory evaluation (odour) of seven papaya pulp samples immediately after processing and at the end of storage are shown in Figure 1. Although control sample (untreated pulp) was scored highest by all the panellists at day 0 , it spoiled after 3 days of storage. Initially, samples with cinnamon oil (ST3, ST5, and ST7) received lower mean scores compared to similar samples without cinnamon oil (ST2, ST4, and ST6) as the odour of 200 ppm cinnamon essential oil was noted immediately after processing. However, cinnamon added samples received higher scores than samples without cinnamon oil after 8 weeks of storage under ambient conditions. At the end of 8 weeks of 
storage, the cinnamon content of cinnamon added samples was almost negligible and panellist did not notice its odour. Although appearances of all the treated samples were not different from each other soon after processing, samples with higher $\mathrm{pH}$ (ST1, ST2, and ST3) had lower scores as compared to low pH samples (ST4, ST5, ST6, and ST7) after 8 weeks of storage. Unpasteurized sample (ST1) showed separation of liquid and solid layers and gelated portions, whereas samples at pH 5.1 (ST2 and ST3) had clotted appearance, which might have contributed for their lower appearance scores.

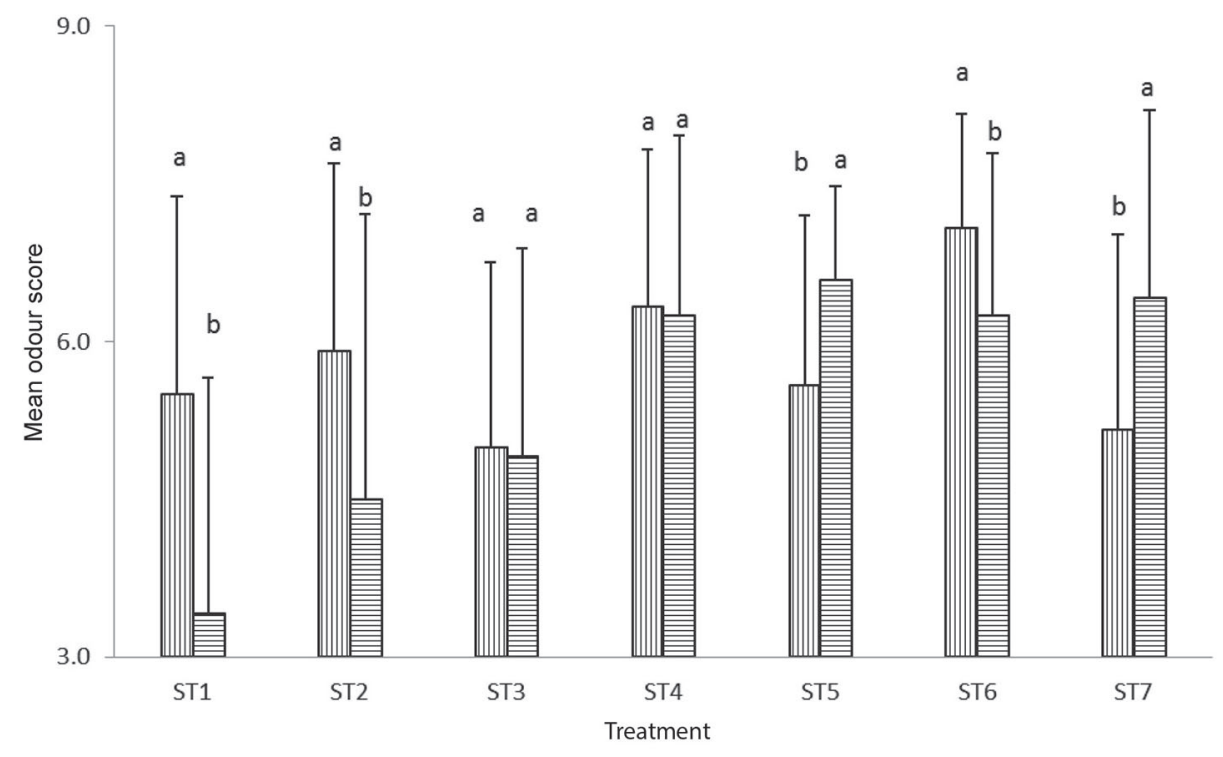

Fig. 1. Total score for papaya pulp samples in odour evaluation immediately after treatment and after 8 weeks of storage at ambient temperature. 四: After processing; 目: after 8 weeks storage.

Values denoted by the same letter in each treatment are not significantly different $(\mathrm{P} \leq 0.05)$

\section{Conclusions}

The results of this study showed that acidification of papaya pulp to $\mathrm{pH}$ value of 4.5 , pasteurization at $75^{\circ} \mathrm{C}$ for $15 \mathrm{~min}$, and addition of $200 \mathrm{ppm}$ cinnamon essential oil can be combined successfully to maintain microbiological quality and colour of papaya pulp. Cinnamon essential oil is a strong antimicrobial agent with typical cinnamon odour, and therefore its use at a lower concentration with mild heat and acidification was helpful in reducing the adverse effect of unpleasant odour, but at the same time preserved the papaya pulp in a cost effective manner. More studies are needed for comparing the quality of papaya pulp preserved with cinnamon essential oil and with other preservative combinations to further increase the shelf life of papaya pulp stored at ambient temperature.

BINDUHEVA U. thanks CSIR for the award of Joint CSIR/ CFTRI-NAM S\&T Fellowship. 


\section{References}

Amalaradjou, M.A.R., Baskaran, S.A., Ramanathan, R., Johny, A.K., Charles, A.S., Kollanoor, A., Valipe, S.R., Mattson, T., Schreiber, D., Juneja, V.K., Mancini, R. \& Venkitanarayanan, K. (2010): Enhancing the thermal destruction of Escherichia coli $\mathrm{O} 157: \mathrm{H} 7$ in ground beef patties by trans-cinnamaldehyde. Fd Microbiol., 27, 841-844.

Baroty, G.S.E., Baky, H.H.A.E., Farag, R.S. \& Saleh, M.A. (2010): Characterization of antioxidant and antimicrobial compounds of cinnamon and ginger essential oils. African J. Biochem. Res., 4, 167-174.

Breidt, F.J.R., Hayes, J.S. \& McFeeters, R.F. (2004): Independent effects of acetic acid and pH on survival of Escherichia coli in simulated acidified pickle products. J. Fd Prot., 67, 12-18.

Chang, H.T., Flath, R.A., Forrey, R.R., Cavaletto, C.G., Nakayama, T.O.M. \& Brekke, J.E. (1973): Development of off odors and off flavors in papaya puree. J. Agric. Fd Chem., 21, 566-570.

Fayyaz, A., Asbi, B.A., Ghasali, H.M., Cheman, Y.B. \& Jinap, S. (1995): Stability studies of papaya pectinesterase. Fd Chem., 53, 391-396.

Gupta, C., Garg, A.P., Uniyal, R.C. \& Kumari, A. (2008): Comparative analysis of the antimicrobial activity of cinnamon oil and cinnamon extract on some food-borne microbes. African J. Microbiol. Res., 2, 247-251.

Gursale, A., Dighe, V. \& Parekh, G. (2010): Simultaneous quantitative determination of cinnamaldehyde and methyl eugenol from stem bark of Cinnamomum zeylanicum Blume using RP-HPLC. J. Chromatog. Sci., 48, 59-62.

Guynot, M.E., Marlín, S., Setu, L., Sanchis, V. \& Ramos, A.J. (2005): Screening for antifungal activity of some essential oils against common spoilage fungi of bakery products. Fd Sci. Technol. Int., 11, 25-32.

Meilgaard, M., Civille, G.V. \& CARr, B.T. (1991): Sensory evaluation techniques. Boca Raton, USA: CRC Press. 354 pages.

Moraes, I.C.F., Sampaio, R.M., Queiroz, N.M., De Salles, S.M., Paschoaleti, C.C. \& Perez, V.H. (2011): Mango pulp (Mangifera indica L.) preserved by hurdle technology: physicochemical, microbiologic and rheologic characterization. J. Fd Process. Pres., 35, 610-614.

Mutaku, I., ERKu, W. \& Ashenafi, M. (2005): Growth and survival of Escherichia coli O157:H7 in fresh tropical fruit juices at ambient and cold temperatures. Int. J. Fd Sci. Nutr., 56, 133-139.

Nakamura, Y., Yoshimoto, M., Murata, Y., Shimoishi, Y., Asai, Y., Park, E.Y., Sato, K. \& Nakamura, Y. (2007): Papaya seeds represent a rich source of biologically active isothiocyanate. J. Agric. Fd Chem., 55, 4407-4413.

Namitha, K.K. \& Negi, P.S. (2010): Chemistry and biotechnology of carotenoids. Crit. Rev. Fd Sci. Nutr., 50, 728760.

Namitha, K.K., Archana, S.N. \& Negi, P.S. (2011): Expression of carotenoid biosynthetic pathway genes and changes in carotenoids during ripening in tomato (Lycopersicon esculentum). Fd Func., 2, 168-173.

Penteado, A.L. \& Leitao, M.F.F. (2004): Growth of Salmonella enteritisdis in melon, watermelon and papaya pulp stored at different times and temperatures. Fd Cont., 15, 369-373.

Ranganna, S. (1997): Handbook of analysis and quality control for fruit and vegetable products. Tata McGraw Hill Publishers, New Delhi, India, 1112 pages.

Tajkarimi, M.M., Ibrahim, S.A. \& Cliver, D.O. (2010): Antimicrobial herb and spice compounds in food. Fd Cont., 21, 1199-1218.

Vanderzant, C. \& Splittstoesser, D. (1992): Compendium of methods for the microbial examination of foods. APHA. Washington DC, USA, 1219 pages. 